\title{
USE OF THE ABI TECHNIQUE TO MEASURE THE MECHANICAL PROPERTIES OF ALUMINIUM ALLOYS: EFFECT OF CHEMICAL COMPOSITION ON THE MECHANICAL PROPERTIES OF THE ALLOYS
}

\author{
UPORABA TEHNIKE ABI ZA MERJENJE MEHANSKIH \\ LASTNOSTI ALUMINIJEVIH ZLITIN: VPLIV KEMIJSKE SESTAVE \\ NA MEHANSKE LASTNOSTI ZLITIN
}

\author{
Maxim Puchnin ${ }^{1}$, Oleksandr Trudonoshyn ${ }^{1,2}$, Olena Prach ${ }^{1,2,3}$ \\ ${ }^{1}$ Czech Technical University in Prague, Karlovo náměstí 13, 12135 Prague 2, Czech Republic \\ ${ }^{2}$ National Technical University of Ukraine "KPI", Polytechnichna str. 35, Build. 9, 03056 Kiev, Ukraine \\ ${ }^{3}$ Technische Universität Darmstadt, Karolinenplatz 5, 64289 Darmstadt, Germany \\ maxim.puchnin@fs.cvut.cz \\ Prejem rokopisa - received: 2014-12-08; sprejem za objavo - accepted for publication: 2015-03-10
}

\begin{abstract}
The effects of the chemical composition on the microstructure and mechanical properties were investigated using automated ball-indentation tests, scanning electron microscopy and energy dispersive X-ray analysis. It was observed that the mechanical properties change with the presence of the eutectic and varying excess content of elements. In this work, the automated-ball-indentation $(\mathrm{ABI})$ technique was compared with the standard mechanical tests. The ABI method is based on controlled multiple indentations into a polished surface by a spherical indenter under load. The indentation depth is progressively increased to the maximum, user-specified limit, with intermediate partial unloading. This technique allows to measure the yield strength, stress-strain curve, strength coefficient and strain-hardening exponent. For all these test materials and conditions, the ABI-derived results were in very good agreement with those obtained with the conventional, standard test methods.

Keywords: Al-alloys, microstructure, mechanical properties, ABI tests

Vpliv kemijske sestave na mikrostrukturo in mehanske lastnosti je bil preiskovan z avtomatskim preizkusom vtiskovanja krogle, z vrstično elektronsko mikroskopijo in z energijsko disperzijsko rentgensko analizo. Opaženo je bilo, da se mehanske lastnosti spreminjajo s prisotnostjo evtektika in s spreminjanjem vsebnosti presežnih elementov. V prispevku je bila preverjena metoda avtomatskega vtiskanja kroglice $(\mathrm{ABI}) \mathrm{z}$ običajnimi mehanskimi preizkusi. ABI metoda temelji na kontroliranih večkratnih vtiskih kroglastega vtiskača v polirano površino. Globina vtiskov progresivno narašča do maksimalne, z uporabnikom določene meje, s takojšnjo vmesno razbremenitvijo. Ta tehnika omogoča merjenje meje plastičnosti, krivulje napetost-raztezek, koeficienta trdnosti in eksponenta napetostnega utrjevanja. Za vse pogoje preizkušanja materiala so dobljeni ABI rezultati skladni z rezultati, dobljenimi iz običajnih metod preizkušanja.

Ključne besede: Al-zlitine, mikrostruktura, mehanske lastnosti, ABI preizkusi
\end{abstract}

\section{INTRODUCTION}

The growing demand for more fuel-efficient and ecological vehicles to reduce energy consumption and air pollution is a challenge for the automotive and aircraft industries. The characteristic properties of aluminum, high strength-to-weight ratio, good formability, good electrical mass conductivity, unique corrosion behavior and recycling potential make it the essential material for the applications such as fuel-efficient transportation vehicles, building construction, and food packaging. ${ }^{1}$

$\mathrm{Si}$ in Al-alloys improves the corrosion resistance of the alloys. An addition of Si to composites significantly affects the diffusion of $\mathrm{Mg}$ and $\mathrm{Si}$ in an $\mathrm{Al}$ liquid. Also, when $\mathrm{Si}$ is used together with $\mathrm{Mg}$, they create heat-treatable alloys. An extra $\mathrm{Si}$ content in $\mathrm{Al}-\mathrm{Mg}_{2} \mathrm{Si}-\mathrm{Si}$ composites leads to an increase of the solidification range. The aspect ratio of the eutectics and the size of primary particles decrease with the increasing $\mathrm{Si}$ content in $\mathrm{Al}-\mathrm{Mg}_{2} \mathrm{Si}$ composites. ${ }^{2,3}$

$\mathrm{Mg}$ in Al-alloys increases the weldability, improves the corrosion resistance and decreases the weight of alloys. An addition of $\mathrm{Mg}$ to aluminium alloys can increase the hardness and strength of the materials. ${ }^{4}$ An extra amount of $\mathrm{Mg}$ in the $\mathrm{Al}-\mathrm{Mg}_{2} \mathrm{Si}$ system moves the eutectic point to a lower $\mathrm{Mg}_{2} \mathrm{Si}$ concentration. Several authors $^{5-8}$ maintain that an excess of $\mathrm{Mg}$ in $\mathrm{Al}-\mathrm{Mg}_{2} \mathrm{Si}$ alloys can promote the formation of primary $\mathrm{Mg}_{2} \mathrm{Si}$. It also shows that increasing the $\mathrm{Mg}$ addition decreases the volume fraction of the $\alpha$-Al matrix and increases the volume fraction of the $\mathrm{Al}-\mathrm{Mg}_{2} \mathrm{Si}$ eutectic.

$\mathrm{Fe}$ is the most common impurity found in $\mathrm{Al}$. Fe reduces the grain size of an alloy, but decreases its hardness and strength, and also increases the brittleness. Mn improves the corrosion resistance and decreases the negative effect of Fe. ${ }^{9,10}$ 
Table 1: Nominal composition of alloys, in mass fractions (w/\%) (Al-bal.)

Tabela 1: Nominalna sestava zlitin, v masnih deležih (w/\%) (Al-ostalo)

\begin{tabular}{|c|c|c|c|c|c|c|c|c|}
\hline Alloys & $\mathrm{Mg}$ & $\mathrm{Si}$ & Mn & $\mathrm{Fe}$ & $\mathrm{Ti}$ & $\mathrm{Cu}$ & $\mathrm{Zn}$ & Comment \\
\hline AlMg6Mn (M3) & 6.0 & 0.4 & 0.6 & 0.3 & 0.1 & 0.1 & 0.1 & $\mathrm{Al}-1 \mathrm{Mg}_{2} \mathrm{Si}-5 \mathrm{Mg}$ \\
\hline AlMg7SiMn (MS1) & 7.0 & 1.0 & 0.6 & 0.02 & 0.1 & 0.05 & 0.05 & $\mathrm{Al}-3 \mathrm{Mg}_{2} \mathrm{Si}-5 \mathrm{Mg}$ \\
\hline AlMg7Si2Mn (MS2) & 7.0 & 2.0 & 0.6 & 0.02 & 0.1 & 0.05 & 0.05 & $\mathrm{Al}-6 \mathrm{Mg}_{2} \mathrm{Si}-3 \mathrm{Mg}$ \\
\hline AlMg5Si2Mn (M59) & 5.0 & 2.0 & 0.6 & 0.02 & 0.1 & 0.05 & 0.05 & $\mathrm{Al}-6 \mathrm{Mg}_{2} \mathrm{Si}-1 \mathrm{Mg}$ \\
\hline AlMg7Si3Mn (MS3) & 7.0 & 3.0 & 0.6 & 0.02 & 0.1 & 0.05 & 0.05 & Al-9Mg $\mathrm{Mgi}_{2}-1 \mathrm{Mg}$ \\
\hline AlMg7Si4Mn (MS4) & 7.0 & 4.0 & 0.6 & 0.02 & 0.1 & 0.05 & 0.05 & $\mathrm{Al}-10.5 \mathrm{Mg}_{2} \mathrm{Si}-0.5 \mathrm{Si}$ \\
\hline AlMg7Si5Mn (MS5) & 7.0 & 5.0 & 0.6 & 0.02 & 0.1 & 0.05 & 0.05 & $\mathrm{Al}-10.5 \mathrm{Mg}_{2} \mathrm{Si}-1.5 \mathrm{Si}$ \\
\hline AlSi7Mg (S1) & 0.3 & 6.9 & 0.02 & 0.2 & - & 0.05 & 0.05 & Al-7Si \\
\hline
\end{tabular}

The main objective of this paper is to investigate the influence of the chemical composition on the mechanical properties and structures of Al-alloys.

The determination of the mechanical properties of materials with non-conventional techniques has been an
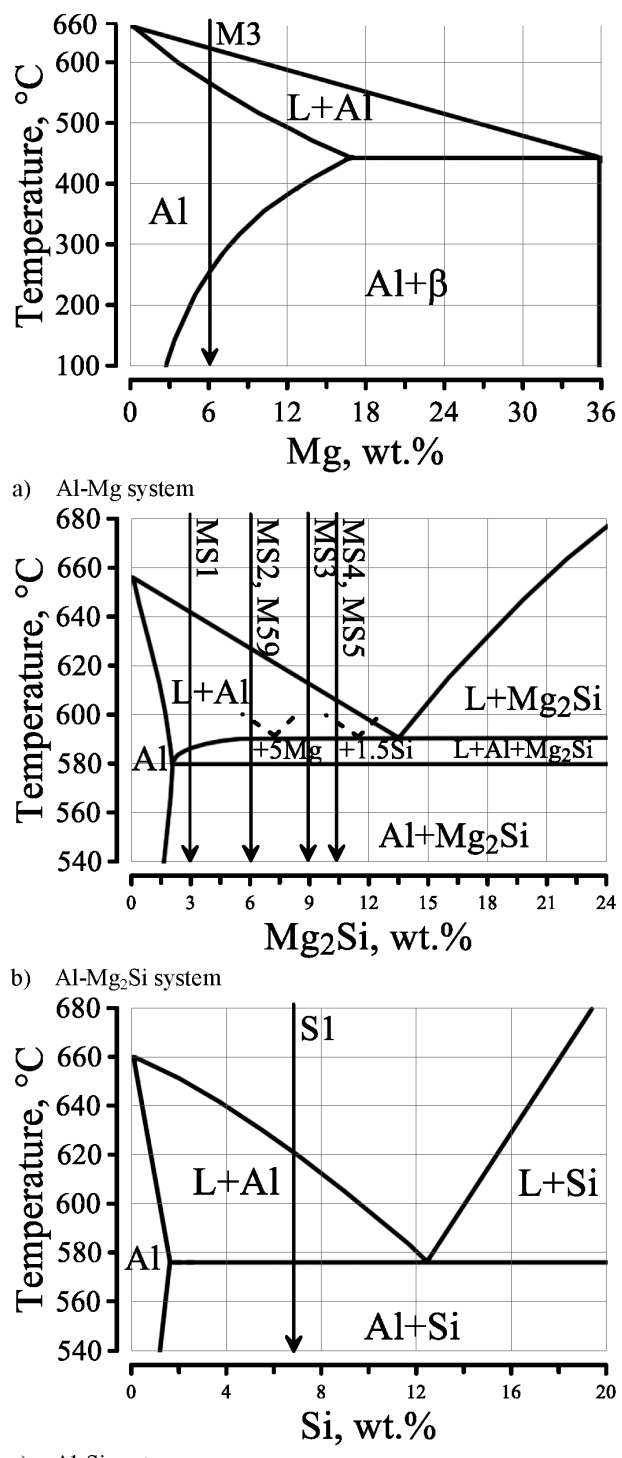

c) Al-Si system

Figure 1: Equilibrium-phase diagrams

Slika 1: Ravnotežni fazni diagrami active area of research for a long time. Among some non-destructive methods for determining the mechanical properties of materials, a semi-destructive type of testing, called automated ball indentation (ABI), has been developed. The automated-ball-indentation technique is used to measure material properties when a tensile test cannot be applied: in welded parts with a continuous property variation, in brittle materials with an unstable crack growth during preparation and specimen testing, in samples with a high porosity and in the parts of the present structural use. ${ }^{11,12}$

\section{MATERIALS AND METHODS}

The chemical compositions of the evaluated alloys are shown in Table $\mathbf{1}$ and Figure $\mathbf{1 .}$

All the alloys were prepared in an electric-resistance furnace using graphite crucibles. High-purity Al (A99.997), AlMg50, AlSi25 and AlMn26 were used as master alloys. The melt with a temperature of 720 ${ }^{\circ} \mathrm{C} \pm 5{ }^{\circ} \mathrm{C}$ was being degassed under an argon atmosphere for $10 \mathrm{~min}$.

Hardness was measured using a Brinell-hardness testing machine (EMCOTEST M4C ) with a ball diameter of $2.5 \mathrm{~mm}$ and a load of $62.5 \mathrm{~kg}$; where the load time was $10 \mathrm{~s}$. Microhardness tests were performed on a polished non-etched specimens using a LECO M-400G1 microhardness tester, HV0.05 with the standard indentation time.

Tensile tests were performed using a testing machine (INSTRON 5582, USA) according to the EN ISO 6892-1 standard. Tensile samples were also prepared according to this standard.

Indentation tests were performed with a special device (patent CZ 304637 B1), which is capable, due to its design, of continuous recording of the load and indentation depth of the used indenter. The system includes a recording device, an analog-to-data converter, a PC with software, and an Instron 5582 tensile-testing machine as the force-producing mechanism. The maximum load indentation was $2.5 \mathrm{kN}$ and the indenter diameter was 5 $\mathrm{mm}$. Plane-parallel samples were used for the ABI testing. 


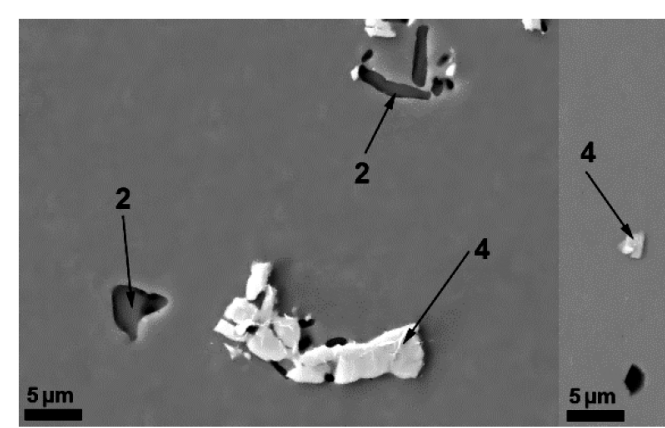

a) M3

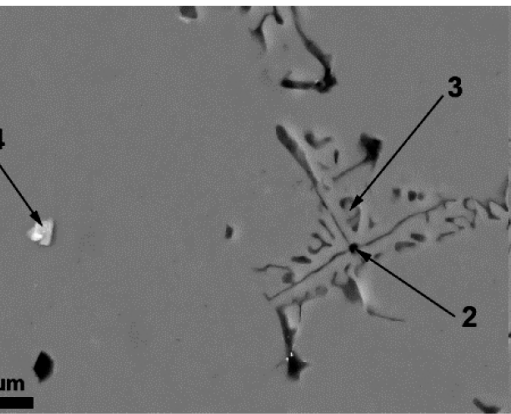

b)

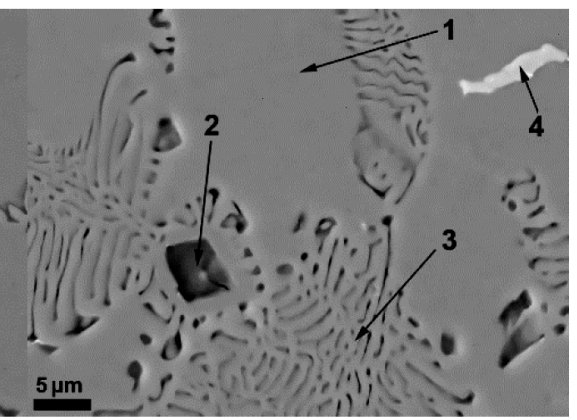

c)
MS2

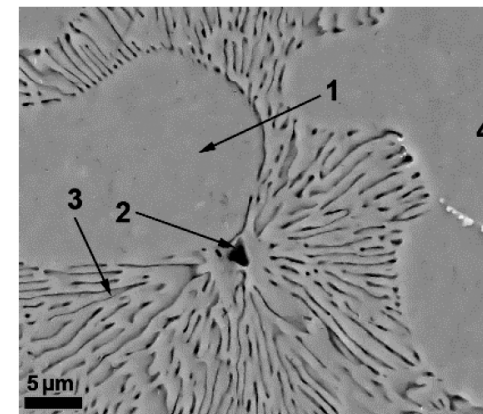

d) MS3

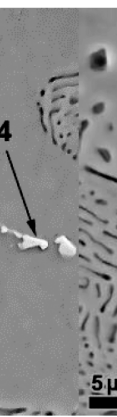

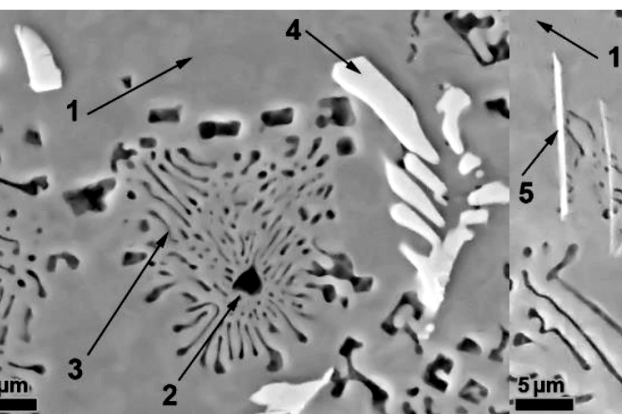

e) MS4

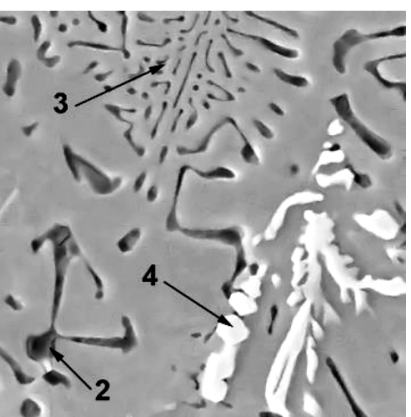

f) MS5

Figure 2: Microstructures of as-cast state of Al-Mg-Si-Mn alloys: a) AlMg6Mn (M3), b) AlMg7SiMn (MS1), c) AlMg7Si2Mn (MS2), d) AlMg7Si3Mn (MS3), e) AlMg7Si4Mn (MS4), f) AlMg7Si5Mn (MS5), (according to the Table 1). The names of phases: 1. Matrix of $\alpha$-A1, 2. Primary $\mathrm{Mg}_{2} \mathrm{Si}$ phase, 3. Eutectic of $\mathrm{Al}-\mathrm{Mg}_{2} \mathrm{Si}$, 4. $\alpha-\mathrm{Al}_{15}(\mathrm{Mn}, \mathrm{Fe})_{3} \mathrm{Si}_{2}, \beta-\mathrm{Al}_{5}(\mathrm{Mn}, \mathrm{Fe}) \mathrm{Si}, 5 . \delta-\mathrm{Al}_{4} \mathrm{Si}_{2}(\mathrm{Mn}, \mathrm{Fe})$.

Slika 2: Mikrostruktura zlitin Al-Mg-Si-Mn, v litem stanju: a) AlMg6Mn (M3), b) AlMg7SiMn (MS1), c) AlMg7Si2Mn (MS2), d) AlMg7Si3Mn (MS3), e) AlMg7Si4Mn (MS4), f) AlMg7Si5Mn (MS5), (glede na Tabelo 1). Imena faz: 1. Osnovna $\alpha$-Al, 2. Primarna Mg 2 Si faza, 3. Evtektik Al-Mg $\mathrm{Mg}_{2} \mathrm{Si}, 4$. Mn-faza $\mathrm{Al}_{6}(\mathrm{Mn}, \mathrm{Fe}), \alpha-\mathrm{Al}_{15}(\mathrm{Mn}, \mathrm{Fe})_{3} \mathrm{Si}_{2}, \beta-\mathrm{Al}_{5}(\mathrm{Mn}, \mathrm{Fe}) \mathrm{Si}, 5 . \mathrm{Si}-\mathrm{Mn}$ faza $\delta$ - $\mathrm{Al}_{4} \mathrm{Si}_{2}(\mathrm{Mn}, \mathrm{Fe})$

\section{RESULTS AND DISCUSSION}

\subsection{Microstructure investigation}

Figure 2 presents the polished microstructures of the samples. The microstructures of all the samples consist of primary Al grains (the light areas) and the (Al)+( $\left.\mathrm{Mg}_{2} \mathrm{Si}\right)$ eutectic (grey). The preferential morphology of $\alpha-\mathrm{Al}$ is a globular-rosette morphology and $\mathrm{Al}$ grains are surrounded by eutectic colonies. The (Al) $+\left(\mathrm{Mg}_{2} \mathrm{Si}\right)$ eutectic has a lamellar morphology. Primary $\mathrm{Mg}_{2} \mathrm{Si}$ crystals have a regular polyhedral shape and are located in the centers of the eutectic colonies.

\subsection{Element distribution in $\alpha-A l$ grains}

The $\alpha$-Al matrix of the Al-Mg-Si-Mn alloys contains $\mathrm{Mg}, \mathrm{Si}$ and $\mathrm{Mn}$. It is known that the solubility of $\mathrm{Mg}$ in $\mathrm{Al}$ amounts to $1.4 \%$ and the solubility of $\mathrm{Si}$ is $0.4 \%$ at room temperature. ${ }^{10}$

In the investigated alloys, the $\mathrm{Mg}$ and $\mathrm{Si}$ contents in a solid solution change with an alteration of the $\mathrm{Mg} / \mathrm{Si}$ ratio in the alloys (Table 2). The stoichiometric composition of $\mathrm{Mg}_{2} \mathrm{Si}$ is $66.7 \%$ of amount fractions of $\mathrm{Mg}$ and $33.3 \%$ of amount fractions of $\mathrm{Si}$ (the $\mathrm{Mg} / \mathrm{Si}$ at. ratio is 2.0, and its weight ratio is $1.73: 1$ ). The $\mathrm{Mg}$ content is considered to be in excess when the ratio is more than 2, and the $\mathrm{Si}$ content is in excess when the ratio is less than 2. For all the alloys, the Mn content in the -Al solid solution is $\sim 0.5 \%$ of mass fractions. The existence of an insignificant peak of oxygen in the EDX spectrum is explained with the tendency of $\mathrm{Al}$ and $\mathrm{Mg}$ silicides to

Table 2: Average composition of $\alpha$-Al solid solution in $\mathrm{Al}-\mathrm{Mg}_{2} \mathrm{Si}$ alloys measured with EDX

Tabela 2: Povprečna sestava trdne raztopine $\alpha$-Al v Al- $\mathrm{Mg}_{2} \mathrm{Si}$ zlitinah, izmerjena z EDX

\begin{tabular}{|c|c|c|c|c|c|c|c|}
\hline \multirow{2}{*}{ Alloy } & \multirow{2}{*}{$\begin{array}{c}\mathrm{Mg} / \mathrm{Si} \\
\text { ratio }\end{array}$} & \multicolumn{6}{|c|}{ Chemical composition $(w / \%)$} \\
\hline & & $\mathrm{Mg}$ & $\mathrm{Al}$ & $\mathrm{Si}$ & $\mathrm{Ti}$ & $\mathrm{Mn}$ & $\mathrm{Fe}$ \\
\hline MS1 (AC) & \multirow{3}{*}{7.0} & 5.8 & 93.2 & 0.2 & 0.2 & 0.5 & $<0.1$ \\
\hline MS1 (ST) & & 5.9 & 93.1 & 0.2 & 0.2 & 0.5 & $<0.1$ \\
\hline MS1 (AA) & & 5.9 & 93.2 & 0.1 & 0.2 & 0.5 & $<0.1$ \\
\hline MS2 (AC) & \multirow{3}{*}{3.5} & 3.5 & 95.5 & 0.2 & 0.2 & 0.5 & $<0.1$ \\
\hline MS2 (ST) & & 3.9 & 95.1 & 0.2 & 0.2 & 0.5 & $<0.1$ \\
\hline MS2 (AA) & & 3.7 & 95.4 & 0.1 & 0.2 & 0.5 & $<0.1$ \\
\hline MS3 (AC) & \multirow{3}{*}{2.2} & 2.5 & 96.3 & 0.3 & 0.3 & 0.5 & $<0.1$ \\
\hline $\mathrm{MS} 3$ (ST) & & 2.4 & 96.5 & 0.2 & 0.3 & 0.5 & $<0.1$ \\
\hline MS3 (AA) & & 2.4 & 96.6 & 0.2 & 0.3 & 0.4 & $<0.1$ \\
\hline MS4 (AC) & \multirow{3}{*}{1.8} & 2.1 & 96.6 & 0.5 & 0.3 & 0.4 & $<0.1$ \\
\hline MS4 (ST) & & 1.3 & 97.0 & 0.8 & 0.3 & 0.5 & $<0.1$ \\
\hline MS4 (AA) & & 1.3 & 97.0 & 0.8 & 0.3 & 0.5 & $<0.1$ \\
\hline MS5 (AC) & \multirow{3}{*}{1.4} & 1.5 & 96.6 & 1.1 & 0.3 & 0.4 & $<0.1$ \\
\hline MS5 (ST) & & 0.8 & 95.8 & 1.4 & 0.3 & 0.5 & $<0.1$ \\
\hline MS5 (AA) & & 0.8 & 96.9 & 1.4 & 0.3 & 0.5 & $<0.1$ \\
\hline
\end{tabular}

$\mathrm{AC}-$ as cast state, $\mathrm{ST}-$ after solution treatment $\left(570{ }^{\circ} \mathrm{C}, 60 \mathrm{~min}\right), \mathrm{AA}$ - after artificial aging (at the point of maximum mechanical properties) 
oxidation. The average composition of the $-\mathrm{Al}$ matrix for all the samples is presented in Table 2.

The solution treatment increases the concentration of $\mathrm{Mg}$ and decreases the concentration of Si (Table 2) in the solid solutions in the MS1 and MS2 alloys (the alloys with an excess $\mathrm{Mg}$ concentration). The artificial aging leads to a further reduction in the concentration of $\mathrm{Si}$ (it is connected with a small amount of $\mathrm{Si}$ in the alloys and the tendency of $\mathrm{Mg}$ to form the $\mathrm{Mg}_{2} \mathrm{Si}$ compound), but the concentration of $\mathrm{Mg}$ is back to the initial values.

The situation is different in the MS3, MS4, MS5 alloys. During the solution treatment, taking $60 \mathrm{~min}$, the amount of $\mathrm{Mg}$ reduces and the amount of $\mathrm{Si}$ increases in these alloys. The increase in the concentration of $\mathrm{Si}$ in the solid solution is connected with the dissolution of Mn-containing phases. Aging does not significantly change the chemical composition of $\alpha$-Al (Table 2).

\subsection{Mn- and Si-containing phases}

Due to a poor solubility, $\mathrm{Fe}$ with $\mathrm{Si}$ and $\mathrm{Al}$ in the Al-Mg-Si alloys constitute acicular-shaped intermetallic inclusions, which reduce the mechanical properties of the alloys. The investigated alloys are additionally doped by $0.6 \% \mathrm{Mn}$ to neutralize the negative effect ${ }^{13-15}$ of the Fe-containing phase. As it is shown by other studies, an addition of $0.6 \%$ of mass fraction of $\mathrm{Mn}$ in the alloy with a nominal composition of Al-7Mg-3Si improves its mechanical properties. Thus, the tensile strength and yield strength of the alloy with the Mn addition increase on average by $30 \%$.

Some authors ${ }^{13}$ reported that in the alloy with a nominal composition of $\mathrm{Al}-7 \mathrm{Mg}-5 \mathrm{Si}(w / \%)$, the $\mathrm{Al}-\mathrm{Mg}_{2} \mathrm{Si}$ eutectic and Al-Si eutectic are formed. However, the Al-Si eutectic was not detected in the alloy with a nominal composition of Al-7Mg-5Si-Mn (Figure 2f). Therefore, the excess $\mathrm{Si}$ with $\mathrm{Mn}$ and Fe form several types of the Mn-phase in the submitted alloys.

The morphologies of all the types of the Mn-containing phases observed in the MS-series are shown in Figure 2. These phases can be identified as $\mathrm{Al}_{6}(\mathrm{Mn}, \mathrm{Fe})$, $\alpha-\mathrm{Al}_{15}(\mathrm{Mn}, \mathrm{Fe})_{3} \mathrm{Si}_{2}, \quad \beta-\mathrm{Al}_{5}(\mathrm{Mn}, \mathrm{Fe}) \mathrm{Si}, \delta-\mathrm{Al}_{4}(\mathrm{Mn}, \mathrm{Fe}) \mathrm{Si}_{2}$. The first two types are found in the alloys with the ratio of $\mathrm{Mg} / \mathrm{Si}$ greater than 2 (M3, MS1, MS2, MS3, M59). Phases $\beta$ and $\delta$ are found in the alloys with the ratio of $\mathrm{Mg} / \mathrm{Si}$ lower than 2 (MS4, MS5). The $\delta$-phase is unstable and it disintegrates during the heat treatment. ${ }^{15-17}$

\subsection{Eutectic}

The EDX spectra of the lamellas excluding $\mathrm{Al}$ from the quantification showed a composition very close to the stoichiometry of $\mathrm{Mg}_{2} \mathrm{Si}$. The EDX spectra of interlamellar spacing show high concentrations of $\mathrm{Mg}$ and $\mathrm{Si}$. With the increase in $\mathrm{Mg}$ and $\mathrm{Si}$, the $\mathrm{Al}-\mathrm{Mg}_{2} \mathrm{Si}$ eutectic volume fraction grows bigger. ${ }^{18}$

With the addition of extra $\mathrm{Mg}$ into the $\mathrm{Al}-\mathrm{Mg}_{2} \mathrm{Si}$ system, the eutectic point moves towards the corner with
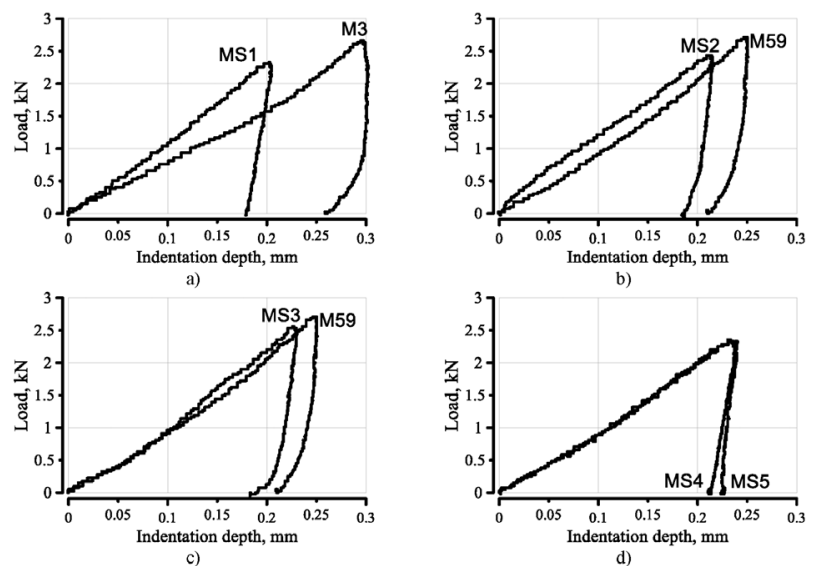

Figure 3: $\mathrm{ABI}$ indentation curves Slika 3: ABI krivulje vtiskovanja

a lower $\mathrm{Mg}_{2} \mathrm{Si}$ concentration and the volume of the $\mathrm{Al}-\mathrm{Mg}_{2} \mathrm{Si}$ eutectic increases.

With the addition of extra $\mathrm{Si}$ into the $\mathrm{Al}-\mathrm{Mg}_{2} \mathrm{Si}$ alloys, the eutectic point moves to a higher $\mathrm{Al}$ concentration and the volume of the $\mathrm{Al}-\mathrm{Mg}_{2} \mathrm{Si}$ eutectic increases. In the AlMg7Si5Mn alloy (with $1.5 \%$ of mass fractions of excess $\mathrm{Si}$ and $0.6 \%$ of mass fractions of $\mathrm{Mn}$ ) the volume fraction of the $\mathrm{Al}-\mathrm{Mg}_{2} \mathrm{Si}$ eutectic reaches its maximum.

\subsection{Reproducibility of the results of classical tests and ABI tests}

Figure 3 represents the dependencies of the indentation-depth load, recorded in the ABI study. They show how the material behaves in the research process, which consists of three parts: the load, the holding at the maximum force and the unloading. The growing part of the curve describes the process of loading. This process has elastic and elastic-plastic sections. ${ }^{19}$ Then, after the holding at the maximum force for $10 \mathrm{~s}$, the unloading process begins. The waning part of the curve describes the process of unloading. The point where the curve intersects with the $x$-axis corresponds to the plastic indentation depth $\left(h_{\mathrm{p}}\right)$. The difference between the plastic depth and the depth of the maximum load $\left(h_{\max }\right)$ corresponds to the elastic depth $\left(h_{\mathrm{s}}\right)$.

For the results validation, the data obtained with the $\mathrm{ABI}$ method were compared with the data obtained with the classical methods (Table 3 ).

The hardness was calculated with Equation (1) and Equation $(2)^{20}$ was used to determine the tensile strength $\left(R_{\mathrm{m}}\right)$ :

$$
\begin{aligned}
& H B=\frac{P}{\pi D h} \\
& R_{\mathrm{m}}=c \cdot H B
\end{aligned}
$$

where: $H B$ - Brinell hardness, $P-\operatorname{load}(\mathrm{kN})($ Figure 3), $D$ - diameter of indenter $(\mathrm{mm}), h$ - indentation depth (mm) (Figure 3), $c$ - coefficient of uncertainty for the presented series of alloys with a value of $2.8 .^{20}$ 
Table 3: Comparison of the results obtained with classical methods and ABI method Tabela 3: Primerjava dobljenih rezultatov s klasičnimi metodami in z ABI metodo

\begin{tabular}{|c|c|c|c|c|c|c|c|c|c|}
\hline State & Method & S1 & M3 & M59 & MS1 & MS2 & MS3 & MS4 & MS5 \\
\hline \multirow{6}{*}{$\begin{array}{l}\text { As-cast } \\
\text { state }\end{array}$} & $\mathrm{HB}, \mathrm{ABI}$ & 72 & 65.0 & 82.3 & 83.6 & 83.9 & 89.4 & 70.0 & 66.2 \\
\hline & $\mathrm{HB}^{*}$ & 75 & 65.0 & 81.0 & 84.0 & 86.8 & 87.8 & 71.1 & 69.0 \\
\hline & $R_{\mathrm{p} 0.2},(\mathrm{MPa}), \mathrm{ABI}$ & 180.2 & 145.6 & 166.4 & 194.1 & 134.4 & 223.9 & 145.5 & 124.8 \\
\hline & $R_{\mathrm{p} 0.2},(\mathrm{MPa})^{*}$ & 182.5 & 130.0 & 155.5 & 169.4 & 155.3 & 203.5 & 137.9 & 123.5 \\
\hline & $R_{\mathrm{m}},(\mathrm{MPa}), \mathrm{ABI}$ & 201.6 & 179.5 & 226.1 & 229.5 & 230.5 & 245.6 & 192.4 & 182.0 \\
\hline & $R_{\mathrm{m}},(\mathrm{MPa})^{*}$ & 205.1 & 180.0 & 219.9 & 199.4 & 223.1 & 239.8 & 185.6 & 163.5 \\
\hline \multirow{2}{*}{$\begin{array}{l}\mathrm{ST} 1 \mathrm{~h}, \\
570{ }^{\circ} \mathrm{C}\end{array}$} & $\mathrm{HB}, \mathrm{ABI}$ & - & - & 73.0 & 79.1 & 70.5 & 73.1 & 71.1 & 78.7 \\
\hline & $\mathrm{HB}^{*}$ & - & - & 71.0 & 77.5 & 69.6 & 73.2 & 71.1 & 75.5 \\
\hline \multirow{6}{*}{$\begin{array}{c}\text { AA } \\
(1 \mathrm{~h}, \\
570{ }^{\circ} \mathrm{C}+ \\
1.5 \mathrm{~h}, \\
\left.75^{\circ} \mathrm{C}\right)\end{array}$} & $\mathrm{HB}, \mathrm{ABI}$ & 90.0 & - & 93.6 & 83.6 & 80.9 & 99.5 & 100.4 & 107.3 \\
\hline & $\mathrm{HB}^{*}$ & 90.0 & - & 96.1 & 82.2 & 79.6 & 100.7 & 101.9 & 113.7 \\
\hline & $R_{\mathrm{p} 0.2},(\mathrm{MPa}), \mathrm{ABI}$ & 194.1 & - & 155.4 & 194.1 & 145.6 & 179.2 & 224.0 & 233.0 \\
\hline & $R_{\mathrm{p} 0.2},(\mathrm{MPa})^{*}$ & 171.9 & - & 175.3 & 174.2 & 164.2 & 200.6 & 227.1 & 200.8 \\
\hline & $R_{\mathrm{m}},(\mathrm{MPa}), \mathrm{ABI}$ & 243.0 & - & 257.1 & 229.7 & 222.4 & 273.1 & 275.8 & 294.7 \\
\hline & $R_{\mathrm{m}},(\mathrm{MPa})^{*}$ & 256.9 & - & 256.3 & 226.2 & 222.1 & 262.4 & 264.9 & 280.7 \\
\hline
\end{tabular}

* - Classic methods

The methodology from the reference ${ }^{20}$, Equations (3) and (4), was used to determine the yield strength $\left(R_{\mathrm{p} 0.2}\right)$ :

$$
\begin{aligned}
R_{\mathrm{p} 0.2} & =c \cdot H M=\frac{c \cdot P}{\pi a^{2}} \\
a & =\sqrt{D h-h^{2}}
\end{aligned}
$$

where: $c$ - coefficient of uncertainty (2.8), HM - Meyer hardness, $a-$ contact radius ( $\mathrm{mm})$.

The differences between the two curves given in the diagrams (Figure 3) may be related to the following parameters taken into account in Equation (1):

1. The difference in the value of the load $(P)$, which leads to a change in the indentation depth.

2. The difference in the hardness of the materials $(H B)$.

Figure 3 shows the indentation curves of the alloys with a difference in the amount of one component $(\mathrm{Mg}$, $\mathrm{Si}, \mathrm{Mg}_{2} \mathrm{Si}$ ). The results of the ABI tests are shown in Table 3.

The calculation of the standard deviation shows that the hardness value is determined with a sufficiently high accuracy. The average deviation is about 2-3\%. The tensile strength (defined by the $H B$ values) has a good accuracy (its average deviation is $3-5 \%$ ).

The values of the average standard deviation of the yield strength are quite high (9-16\%), but in some tests the accuracy is $1 \%$. This can be explained in the following manner: the load, at which the deformation is detected in the track $(0.2 \%)$ is about $100 \mathrm{~N}$ and the measurement device determines the load with an accuracy of $24 \mathrm{~N}-50 \mathrm{~N}$. This is sufficient for the determination of the total hardness, but it is not enough for the determination of the hardness at the load of $P_{0.2}$. It is planned to increase the accuracy of the determination of this and other parameters.

\subsection{Influence of the chemical composition on the me- chanical properties}

As it can be seen from Table 3, the mechanical properties of the cast $\mathrm{Al}-\mathrm{Mg}_{2} \mathrm{Si}$ alloys do not increase with the growth of the $\mathrm{Mg}$ content (Figure $\mathbf{3 b}$, alloys MS2 and M59 - alloys with similar values of $\mathrm{Mg}_{2} \mathrm{Si}$ and different values of $\mathrm{Mg}$ ). Similar results of the $\mathrm{Mg}$ behavior in Al-alloys were obtained in another study. ${ }^{21}$

An analysis of the literature data ${ }^{3,13}$ showed that the mechanical properties of the Al- $\mathrm{Mg}_{2} \mathrm{Si}-\mathrm{Si}$ alloys with an increased amount of Si are improved. However, in these works the mechanical properties are given after the heat treatment of the alloys. In the considered series of alloys, extra $\mathrm{Si}$ with $\mathrm{Mn}$ forms a metastable acicular-shaped $\delta$ - $\mathrm{Al}_{4}(\mathrm{Mn}, \mathrm{Fe}) \mathrm{Si}_{2}$ phase, which deteriorates the properties of the alloys in the as-cast state, and this phase dissolves during the homogenization process.

As can be seen in Table $\mathbf{3}$, the hardness and the tensile strength of the cast $\mathrm{Al}-\mathrm{Mg}_{2} \mathrm{Si}$ alloys can relate to the size and morphology of the eutectic and primary $\mathrm{Mg}_{2} \mathrm{Si}$ phase (M3 and MS1, M59 and MS3 are alloys with similar values of $\mathrm{Mg}$ and different values of $\mathrm{Mg}_{2} \mathrm{Si}$ ). Hence, the mechanical properties grow with the increasing volume fraction of $\mathrm{Mg}_{2} \mathrm{Si}$. Similar results were obtained in a reference study. ${ }^{6}$

\section{CONCLUSIONS}

The comparison of the results obtained with classical and ABI methods shows the following:

- The differences in the values of the hardness and tensile strength, obtained with different methods, do not exceed $5 \%$ (with the standard error for such measurements of $10 \%$ ). 
- The error of the yield-strength measurement is greater than $10 \%$ (and varies from $1 \%$ to $16 \%$ ). This problem can be solved by increasing the sensitivity of the device at low values of the load.

- The analysis of the results of the hardness and tensile tests shows the following:

- Excess Mg does not have a significant effect on the mechanical properties of the alloys.

- Metastable $\delta$ - $\mathrm{Al}_{4}(\mathrm{Mn}, \mathrm{Fe}) \mathrm{Si}_{2}$ phases are formed in the alloys with excess $\mathrm{Si}$. This leads to a degradation of the mechanical properties.

- The main strengthening phase in the as-cast state of the studied alloys is the $\mathrm{Al}-\mathrm{Mg}_{2} \mathrm{Si}$ eutectic.

\section{Acknowledgments}

The authors gratefully thank the Visegrad Fund and DAAD for their support in the research. Also, the authors would like to thank doc. Ing. Jirí Cejp, C Sc. and doc. Ing. Jirí Janovec, C Sc. for their help with the tensile tests, and Ing. Jakub Horník, Ph.D., for supervising the present investigations.

This work was supported by the Ministry of Education, Youth and Sport of the Czech Republic, program NPU1, the project with Nos. LO1207 and SGS13/ 186/OHK2/3T/12 - Research on the influence of surface treatment on the improvement of service life and reliability of exposed water turbine's components.

\section{REFERENCES}

${ }^{1}$ I. N. Fridlyander, V. G. Sister, O. E. Grushko, V. V. Berstenev, L. M. Sheveleva, L. A. Ivanova, Aluminium alloys: promising materials in the automotive industry, Metal Science and Heat Treatment, 44 (2002) 9-10, 365-370, doi:10.1023/A:1021901715578

${ }^{2}$ J. Zhang, Y. Q. Wang, B. Yang, Effects of Si content on the microstructure and tensile strength of an in situ Al-Mg2Si composite, Journal of Materials Research, 14 (1999) 1, 68-74, doi:10.1557/JMR. 1999.0012

${ }^{3}$ Y. Wang, H. Liao, Y. Wu, J. Yang, Effect of Si content on microstructure and mechanical properties of $\mathrm{Al}-\mathrm{Si}-\mathrm{Mg}$ alloys, Materials and Design, 53 (2014), 634-638, doi:10.1016/j.matdes.2013.07.067

${ }^{4}$ C. Li, Y. Wu, H. Li, X. Liu, Microstructural formation in hypereutectic Al-Mg2Si with extra Si, Journal of Alloys and Compounds, 477 (2009), 212-216, doi:10.1016/j.jallcom.2008.10.061

${ }^{5}$ J. Zhang, Z. Fan, Y. Q. Wang, B. L. Zhou, Equilibrium pseudobinary Al-Mg2Si phase diagram, Materials Science and Technology, 17 (2001), 494-496, doi:10.1179/026708301101510311

${ }^{6}$ F. Yan, S. Ji, Z. Fan, Effect of Excess Mg on the Microstructure and Mechanical Properties of Al-Mg2Si High Pressure Die Casting Alloys, Materials Science Forum, 765 (2013), 64-68, doi:10.4028/ www.scientific.net/MSF.765.64

${ }^{7}$ A. Furihata, K. Matsuda, J. Y. Nakamura, S. Ikeno, Y. Uetani, Age-hardening behavior and HRTEM observation of precipitates in excess Mg type Al-Mg-Si-Ag alloy, Materials Science Forum, 519-521 (2006), 507-510, doi:10.4028/www.scientific.net/ MSF.519-521.507

${ }^{8}$ K. Matsuda, T. Yoshida, T. Wada, A. Yoshida, U. Uetani, T. Sato, A. Kamio, S. Ikeno, Precipitation Sequence in Al-Mg-Si Alloys with Excess Magnesium, J. Japan Inst. Metals, 62 (1998) 8, 718-726

${ }^{9}$ J. Gilbert Kaufman, E. L. Rooy, Aluminum Alloy Castings: Properties, Processes, and Applications, ASM International, Materials Park, OH 2004

${ }^{10}$ V. S. Zolotorevsky, N. A. Belov, M. V. Glazoff, Casting aluminium alloys, Elsevier, Amsterdam 2007, doi:10.1016/B978-0080453705.50003-1

${ }^{11}$ H. Lee, J. H. Lee, G. M. Pharr, A numerical approach to spherical indentation techniques for material property evaluation, Journal of the Mechanics and Physics of Solids, 53 (2005), 2037-2069, doi:10.1016/j.jmps.2005.04.007

${ }^{12}$ K. Sharma, P. K. Singh, V. Bhasin, K. K. Vaze, Application of Automated Ball Indentation for Property Measurement of Degraded $\mathrm{Zr} 2.5 \mathrm{Nb}$, Journal of Minerals \& Materials Characterization \& Engineering, 10 (2011) 7, 661-669, doi:10.4236/jmmce.2011. 107051

${ }^{13}$ E. Georgatis, A. Lekatou, A. E. Karantzalis, H. Petropoulos, S. Katsamakis, A. Poulia, Development of a Cast Al-Mg2Si-Si In Situ Composite: Microstructure, Heat Treatment, and Mechanical Properties, Journal of Materials Engineering and Performance, 22 (2013) 3, 729-741, doi:10.1007/s11665-012-0337-6

${ }^{14}$ L. C. Doan, K. Nakai, Y. Matsuura, S. Kobayashi, Y. Ohmori, Effects of Excess $\mathrm{Mg}$ and $\mathrm{Si}$ on the Isothermal Ageing Behaviours in the Al-Mg2Si Alloys, Materials Transactions, 43 (2002) 6, 1371-1380, doi:10.2320/matertrans.43.1371

${ }^{15}$ Z. Zhihao, M. Yi, C. Jianzhong, Effect of Mn on microstructures and mechanical properties of Al-Mg-Si-Cu-Cr-V alloy, China Foundry, 9 (2012) 4, 349-355

${ }^{16}$ L. Lia, R. Zhoua, D. Lua, Y. Jianga, R. Zhoua, Effect of Cooling Slope and Manganese on the Microstructure of Hypereutectic Al-Si Alloy with $2 \%$ Fe, Materials Research, 17 (2014) 2, 511-517, doi:10.1590/S1516-14392013005000198

${ }^{17}$ C. Phongphisutthinan, H. Tezuka, T. Sato, Semi-Solid Microstructure Control of Wrought Al-Mg-Si Based Alloys with Fe and Mn Additions in Deformation-Semi-Solid-Forming Process, Materials Transactions, 52 (2011) 5, 834-841, doi:10.2320/matertrans.LMZ201119

${ }^{18}$ S. Otarawanna, C. M. Gourlay, H. I. Laukli, A. K. Dahle, Microstructure Formation in AlSi4MgMn and AlMg5Si2Mn High-Pressure Die Castings, Metallurgical and Materials Transactions A, 40A (2009), 1645-1659, doi:10.1007/s11661-009-9841-1

${ }^{19}$ K. Sharma, V. Bhasin, K. K. Vaze, A. K. Ghosh, Numerical simulation with finite element and artificial neural network of ball indentation for mechanical property estimation, Sadhana, 36 (2011) 2, 181-192, doi:10.1007/s12046-011-0019-3

${ }^{20}$ P. I. Stoev, V. I. Moschenok, Definition of Mechanical Properties of Metals and Alloys on Hardness, Bulletin of V. N. Karazin Kharkiv National University, 601 (2003) 2(22), 106-112

${ }^{21}$ H. Liu, W. J. Song, G. Zhao , C. M. Liu, L. Zuo, Effect of Mg on microstructures and properties of $\mathrm{Al}-\mathrm{Mg}-\mathrm{Si}-\mathrm{Cu}$ aluminium alloys for automotive body sheets, Trans. Nonferrous Met. Soc. China, 15 (2005) 1, 30-31 